\title{
Analisa Komparatif Sifat Fisikokimia Sari Buah dan Konsentrat Sari Buah Antara Hasil Olahan Nanas (Ananas comosus (L) Merr.) Varietas Queen Grade C dan Grade B
}

\author{
Yustita Nuraeni ${ }^{1}$, Susinggih Wijana ${ }^{2}$, dan Bambang Susilo ${ }^{3}$ \\ 1,2, Jurusan Teknologi Industri Pertanian, Fakultas Teknologi Pertanian, \\ Universitas Brawijaya, Malang \\ 3 Jurusan Teknik Mesin Pertanian, Fakultas Teknologi Pertanian, \\ Universitas Brawijaya, Malang \\ 1email: yustitanuraeni@yahoo.com
}

\begin{abstract}
Pineapple plantations around Mount Kelud are pineapple producing centers in East Java. The most commonly planted is Queen, but 10-15\% of the harvest is grade $C$ which is smaller than other grades. This study aims to analyze the properties of the juice and juice concentrate of the pineapple Queen varieties grade $C$, and comparing it with those processed from grade $B$ to determine whether or not there are differences in product properties. In the method, the products are first made, analyzed for their physicochemical properties, and compared using a comparative analysis $t$-test independent. Physicochemical analysis of juice made from grade $C$ and grade $B$, results average value of TPT, water content, total sugar, total acid, viscosity, color La* $b^{*}$, respectively: 15,90 brix and 15,97\% brix; $83.27 \%$ and $83.73 \% ; 14.98 \%$ and $13.96 \%$; $1.01 \%$ and 1.08\%; $5.00 \mathrm{cP}$ and 2.33 cP; 23.63 and 23.73; 6.17 and 6.20; 9.53 and 9.03. The average of that properties in juice concentrate made from grade $C$ and grade $B$, respectively: $63.40^{\circ}$ brix and $63.57 \%$ brix; $31.80 \%$ and $33.53 \% ; 57.95 \%$ and $61.39 \%$; $2.63 \%$ and $2.50 \% ; 293,00 c P$ and $211,33 c P ; 25.93$ and $25.27 ; 8.00$ and $7.57 ; 13.33$ and 12.57. The results of the $t$-test independent shows that all the $t_{\text {count }}$ between (-) 4.604 to (+) 4.604 so that $h_{0}$ is accepted, which means there is no difference in the average physicochemical properties of pineapple juice Queen varieties grade $C$ and grade $B$, and there is no difference in the average physicochemical properties of pineapple juice concentrate Queen varieties grade $C$ and grade $B$
\end{abstract}

Keywords: Pineapple Queen Varieties, juice, juice concentrate

\begin{abstract}
ABSTRAK
Perkebunan nanas di sekitar Gunung Kelud merupakan sentra penghasil nanas di Jawa Timur. Varietas yang umumnya ditanam adalah Queen, namun 10-15\% dari panen merupakan grade $\mathrm{C}$ yang ukurannya lebih kecil dibandingkan grade lainnya. Penelitian ini bertujuan untuk menganalisa sifat sari buah dan konsentrat sari buah nanas varietas Queen grade $\mathrm{C}$, sekaligus membandingkannya dengan yang diolah dari grade $\mathrm{B}$ guna mengetahui ada atau tidaknya perbedaan sifat produk. Pada metodenya, terlebih dahulu dibuat produk-produk tersebut, dianalisa sifat fisikokimianya, dan dibandingkan menggunakan analisa komparatif berupa uji t-test independent. Analisa fisikokimia sari buah nanas yang dibuat dari grade $\mathrm{C}$ dan grade $\mathrm{B}$ menghasilkan nilai rata-rata TPT, kadar air, total gula, total asam, viskositas, warna La*b*, secara berurutan sebagai berikut: 15,90 brix dan 15,97 brix; $83,27 \%$ dan $83,73 \% ; 14,98 \%$ dan $13,96 \% ; 1,01 \%$ dan $1,08 \% ; 5,00$ cP dan 2,33 cP; 23,63 dan 23,73; 6,17 dan 6,20; 9,53 dan 9,03. Ratarata sifat-sifat tersebut pada konsentrat sari buah yang dibuat dari grade $\mathrm{C}$ dan grade $\mathrm{B}$, secara berurutan sebagai berikut: 63,40 brix dan $63,57 \circ$ brix; $31,80 \%$ dan $33,53 \%$; $57,95 \%$ dan $61,39 \% ; 2,63 \%$ dan $2,50 \% ; 293,00$ cP dan $211,33 \mathrm{cP} ; 25,93$ dan 25,27; 8,00 dan 7,57; 13,33 dan 12,57. Hasil analisa t-test independent, menunjukkan seluruh nilai thitung antara (-) 4,604 sampai dengan (+) 4,604 sehingga HO diterima, yang berarti tidak ada perbedaan nilai rata-rata sifat fisikokimia antara sari buah nanas varietas Queen grade $\mathrm{C}$ dengan grade $\mathrm{B}$, dan tidak ada perbedaan nilai rata-rata sifat fisikokimia antara konsentrat sari buah nanas varietas Queen grade $\mathrm{C}$ dengan grade $\mathrm{B}$.
\end{abstract}

Kata kunci: Nanas Varietas Queen, konsentrat sari buah, sari buah. 


\section{Pendahuluan}

Tanaman nanas merupakan tanaman buah yang banyak dibudidayakan di Indonesia. Tanaman ini memiliki nama spesies Ananas comosus (L) Merr dan terdiri dari beberapa varietas diantaranya adalah Cayene, Queen, Spanish, dan Abacaxi (Cahyono, 2012; Samadi, 2014). Berdasarkan data Food and Agriculture Organization of The United Nations (FAO) (2013), pada tahun 2013, produksi nanas di Indonesia menempati urutan ke lima di dunia dengan jumlah produksi sebesar 1,78 juta ton. Mengacu pada data Badan Pusat Statistik (BPS) (2015), Jawa Timur merupakan salah satu daerah penghasil nanas di Indonesia, dengan nilai produksi sebesar 171 ribu ton pada tahun 2015.

Sentra perkebunan nanas di Jawa Timur berada di daerah sekitar Gunung Kelud yang terbagi ke dalam wilayah Kabupaten Kediri dan Kabupaten Blitar. Varietas nanas yang umumnya ditanam di daerah tersebut adalah Queen, namun sebagian berukuran subgrade yang tidak sesuai standar permintaan pasar dan tergolong sebagai grade $C$, sehingga sebagian nanas grade tersebut tidak dipanen atau dibuang. Penyuluh Pertanian Kabupaten Kediri yang bertugas di Gunung Kelud menginformasikan bahwa jumlah nanas subgrade sebesar $10-15 \%$ dari setiap panen, nanas tersebut merupakan nanas yang sudah matang namun berukuran lebih kecil dibandingkan grade lainnya, dan nanas tersebut masih bisa dijual dengan harga jauh lebih murah.

Ciri-ciri nanas Queen antara lain berat buah mencapai 1,1 kg/biji (Samadi, 2014; Paul \& Duarte, 2011). Buah berbentuk kerucut dan mata buah menonjol (Paul \& Duarte, 2011; Siddiq, 2012). Daging buahnya berwarna kuning keemasan, memiliki aroma dan flavor yang baik, rasanya manis dan lezat, dan cocok untuk sari buah (Cahyono, 2012). Selain itu, varietas ini memiliki rasa lebih manis dan kurang masam jika dibandingkan dengan varietas lainnya (Paul \& Duarte, 2011).

Penelitian terkait nanas Queen berukuran kecil diantaranya dilaksanakan oleh Laylatul (2014) yang memanfaatkan nanas subgrade menjadi fruit leather dengan kajian penambahan karaginan dan sorbitol, Septivirta (2014) yang membuat permen jelly dari buah nanas subgrade kajian konsentrasi karagenan dan gelatin, dan Wijayanti (2014) yang membuat permen coklat praline dengan filler permen jelly nanas kajian konsentrasi penambahan karaginan dan sukrosa. Fokus penelitian-penelitian tersebut bukanlah membandingkan kualitas antara produk yang diolah dari nanas Queen subgrade dengan grade lainnya yang berukuran lebih besar.

Nanas Queen merupakan salah satu varietas utama untuk produksi sari buah, dan buah yang berukuran kecil dapat dimanfaatkan sebagai bahan bakunya, yangmana sebutan fruit juice (sari buah) adalah produk yang terdiri dari 100\% sari buah (Featherstone, 2016). Sari buah dapat dipanaskan hingga menghasilkan konsentrat sari buah (Siddiq, 
2012). Konsentrat sari buah tersebut merupakan produk setengah jadi yang dapat digunakan sebagai bahan produksi minuman buah (Sinha, et al., 2012). Berdasarkan hal ini, maka buah nanas Queen grade C berpotensi untuk diolah menjadi sari buah dan konsentrat sari buah yang memiliki nilai komersil, namun belum diperoleh hasil penelitian terkait mengenai ada atau tidaknya perbedaan sifat fisikokimia antara produk yang diolah dari nanas Queen grade C dengan grade B.

Mengacu kepada Falguera \& Ibarz (2014), tahapan pembuatan sari buah jernih, yaitu: pencucian buah menggunakan air bersih; penyeleksian buah; penghancuran dan pengepresan dimana terdapat proses ekstrasi sari buah dari buahnya hingga menghasilkan sari buah single strenght; dan preconcentration yang bisa berupa pasteurisasi.

Pada awal proses pemekatan, sari buah memerlukan proses pasteurisasi pada suhu $95^{\circ} \mathrm{C}$ guna mengeliminasi mikroorganisme dan denaturasi enzim (Ashurst, 2005). Metode pemekatan yang paling umum adalah evaporasi vakum guna menurunkan titik didih (Sinha et al., 2012). Penelitian Assawarachan \& Noomhorm (2010) memekatkan $200 \mathrm{~g}$ sari buah nanas yang memiliki total padatan terlarut (TPT) $12,20^{\circ}$ brix menggunakan rotary vacuum evaporator pada tekanan vakum di bawah 200 mbar dan water bath $55^{\circ} \mathrm{C}$ hingga menghasilkan konsentrat sari buah nanas dengan nilai TPT $60,5^{\circ}$ brix.

Berdasarkan hal-hal tersebut diatas maka buah nanas Queen grade C berpotensi untuk diolah menjadi sari buah dan konsentrat sari buah secara komersiil pada skala industri. Permasalahan terkait hal tersebut diantaranya adalah bagaimana sifat fisikokimia sari buah dan konsentrat sari buah yang diolah dari nanas Queen grade C, dan ada atau tidaknya perbedaan sifatnya dengan yang diolah dari grade lainnya yang lebih besar yaitu grade $B$. Mengacu hal ini, maka penelitian ini bertujuan untuk melakukan analisa sifat sari buah dan konsentrat sari buah hasil olahan nanas Queen grade C, sekaligus membandingkannya dengan yang diolah dari nanas Queen grade B guna mengetahui ada atau tidaknya perbedaan sifat produk diantara keduanya.

Hasil dari penelitian ini diharapkan dapat meningkatkan pengetahuan mengenai karakteristik produk yang dihasilkan dari nanas Queen grade C dan grade B, sekaligus dapat meningkatkan pemanfaatan nanas Queen grade $\mathrm{C}$ tersebut menjadi produk pangan.

\section{Metodologi Penelitian}

Penelitian dilaksanakan di laboratorium Teknologi Agrokimia Jurusan dan Laboratorium Bioindustri Teknologi Industri Pertanian Universitas Brawijaya Malang. Penelitian ini dilaksanakan pada periode Bulan Desember 2016 sampai dengan bulan Februari 2017.

Peralatan untuk pembuatan sari buah dan konsentrat sari buah nanas yaitu: pisau stainless steel, wadah plastik, juicer Electrolux EJE 3000, pengepres hidrolik, kain saring 
\pm 75 mesh, panci porcelain enamel on steel, pocket refractometer PAL-3 Atago, timbangan digital, termometer, gelas ukur, kompor gas, pengaduk, dan rotary vacuum evaporator IKA®'s RV 10 digital.

Bahan baku berupa nanas diperoleh langsung dari daerah Gunung Kelud kecamatan Ngancar, kabupaten Kediri. Nanas (Ananas comosus (L) Merr) yang digunakan varietas Queen grade C dan grade B yang telah matang pohon dengan tanda sebanyak $60 \%-80 \%$ kulit buah telah menguning.

\section{Prosedur Penelitian}

Prosedur penelitian terdiri dari beberapa tahapan, yaitu pembuatan sari buah dan pembuatan konsentrat sari buah, analisa sifat produk dan analisa komparatif terhadap sifat produk tersebut.

\section{Pembuatan Sari Buah}

Tahap pembuatan sari buah nanas yaitu: buah nanas dibuang mahkotanya; dicuci menggunakan air mengandung klorin (sodium hypochlorite) ( $\mathrm{NaClO} 200 \mathrm{mg} / \mathrm{l}$ ); ditiriskan; dikupas; dipotong menjadi ukuran $\pm 3 \mathrm{~cm} \times 3 \mathrm{~cm} \times 3 \mathrm{~cm}$; dilumatkan menggunakan juicer hingga menghasilkan bubur buah nanas; dimasukkan kedalam kain saring berukuran \pm 75 mesh; dipres menggunakan pengepres hidrolik tekanan 100 bar/psi hingga menghasilkan ampas dan sari buah nanas single strength.

\section{Pembuatan Konsentrat Sari Buah}

Tahap pembuatan konsentrat sari buah nanas yaitu: sebanyak $500 \mathrm{ml}$ sari buah nanas single strength dipanaskan di dalam panci hingga mencapai suhu $95^{\circ} \mathrm{C}$ selama 30 detik; didinginkan hingga mencapai suhu $25^{\circ} \mathrm{C}$ dengan cara perendaman panci di dalam air bersuhu $5^{\circ} \mathrm{C}$ sehingga menghasilkan sari buah nanas preconcentrated. Tahap berikutnya, sebanyak $400 \mathrm{ml}$ sari buah nanas preconcentrated dipekatkan menggunakan rotary vacuum evaporator pada tekanan 100 mbar, suhu waterbarth $55^{\circ} \mathrm{C}$, dan perputaran rotary flask $65 \mathrm{rpm}$. Proses pemekatan dihentikan bilamana sari buah mencapai nilai minimum $62,8^{\circ}$ brix. Konsentrat sari buah nanas yang dihasilkan akan dikemas menggunakan botol kaca steril dan dimasukkan kedalam lemari es.

\section{Parameter Pengujian}

Parameter yang diuji pada penelitian yaitu: kadar air (Sudarmadji dkk, 2010), kadar total gula metode anthrone (Apriyantono dkk, 1989), total asam metode AOAC (Amador, 2011), total padatan terlarut (TPT) menggunakan hand refractometer dan hasilnya dinyatakan dalam satuan brix, viskositas menggunakan elcometer $2300 \mathrm{RV}$ dan hasilnya dinyatakan dalam sentipoise (cP), warna menggunakan colorimeter dan hasilnya dinyatakan dalam nilai La*b*. 


\section{Analisis Komparatif}

Jenis data yang dihasilkan berupa data internal atau rasio dari dua sampel yang independen atau tidak saling berkorelasi, sehingga analisis komparatif menggunakan uji t-test independent guna mengetahui perbedaan antara dua data sampel tersebut. Analisis ini mengacu kepada Siregar (2015), dengan langkah-langkah sebagai berikut:

1. Membuat hipotesa

Ho : Tidak ada perbedaan nilai rata-rata antara produk olahan nanas Queen grade C dengan produk olahan nanas Queen grade B

$\mathrm{Ha}$ : Ada perbedaan nilai rata-rata antara produk olahan nanas Queen grade C dengan produk olahan nanas Queen grade B

2. Menentukan tingkat signifikansi (resiko kesalahan), yaitu $\alpha=0,01$ karena uji dua sisi maka nilai $\alpha / 2=0,005$

3. Kaidah pengujian

Jika, $-t_{\text {tabel }} \leq t_{\text {hitung }} \leq t_{\text {tabel }}$, maka Ho diterima

Jika, $t_{\text {hitung }}>t_{\text {tabel}}$, maka Ho ditolak

4. Menghitung thitung dan tabel

a. Membuat tabel

b. Menghitung nilai rata-rata pengukuran kelompok ke-i, rumus sebagai berikut:

$$
\overline{X_{i}}=\frac{\Sigma X_{i}}{N}
$$

Keterangan:

$X_{i}=$ data pengukuran kelompok ke- $i$

$\overline{X_{i}}=$ nilai rata-rata data pengukuran kelompok ke- $i$

$n_{i}=$ jumlah responden kelompok ke- $i$

$S_{1}^{2}=$ nilai varian kelompok ke- $i$

c. Menghitung nilai varian kelompok ke-i $\left(S_{1}^{2}\right)$ dengan rumus sebagai berikut:

$$
S_{i}^{2}=\Sigma \frac{\left(X_{i}-\bar{X}_{i}\right)^{2}}{n_{i}-1}
$$

d. Menghitung nilai $t_{\text {hitung }}$ dengan rumus sebagai berikut:

$$
\frac{\overline{X_{1}}-\bar{X}_{2}}{\sqrt{\frac{\left(n_{1}-1\right) S_{1}^{2}+\left(n^{2}-1\right) S_{2}^{2}}{n_{1}+n_{2}-2}\left(\frac{1}{n_{1}}+\frac{1}{n_{2}}\right)}}
$$

e. Menghitung $t_{\text {tabel }}$ 
Pada taraf signifikasi $\alpha / 2=0,005$ dan $\mathrm{db}=\mathrm{n}-2=6-2=4$, nilai $\mathrm{t}_{(0,005,4)}$ sebesar 4,604 .

5. Membandingkan $t_{\text {hitung }}$ dan $t_{\text {tabel }}$

Jika, $-4,604 \leq$ thitung $\leq 4,604$, maka Ho diterima

Jika, thitung $>4,604$ atau thitung $<-4,604$, maka Ho ditolak

\section{Rancangan Sampel Penelitian}

Sampel pertama penelitian ini adalah sari buah nanas yang dibuat dari nanas Queen grade $C$ dan grade $B$, masing-masing diulang 3 kali sehingga terdapat 6 sampel penelitian. Sampel kedua penelitian ini adalah konsentrat sari buah nanas yang juga dibuat dari nanas Queen grade $C$ dan grade $B$, masing-masing diulang sebanyak 3 kali sehingga juga terdapat 6 sampel penelitian. Total sampel dalam penelitian ini diperolah dari 12 satuan sampel untuk kedua jenis produk.

\section{Hasil dan Pembahasan}

\section{Karakteristik Fisik Buah Nanas Queen Grade C dan Grade B}

Bahan baku sari buah dan konsentrat sari buah pada penelitian ini adalah nanas Queen grade C dan grade B. Pertimbangan nanas Queen grade B yang digunakan sebagai pembanding grade $\mathrm{C}$ adalah nanas grade $\mathrm{B}$ yang digunakan tersebut tergolong nanas berukuran besar yang dapat dihasilkan oleh petani di Gunung Kelud dan sebagian pedagang telah menggolongkannya sebagai grade A. Rata-rata karakteristik fisik buah nanas Queen grade C dan grade B yang digunakan pada penelitian ini sebagaimana Tabel 1.

Tabel 1. Karakteristik Fisik Buah Nanas Queen Grade C dan Grade B

\begin{tabular}{ccc}
\hline Karakteristik & \multicolumn{2}{c}{ Nanas Queen } \\
\cline { 2 - 3 } & Grade C & Grade B \\
\hline Rata-rata bobot buah utuh $(\mathrm{g})$ & 381,56 & 791,00 \\
Rata-rata bobot buah tanpa mahkota $(\mathrm{g})$ & 324,83 & 698,00 \\
Rata-rata tinggi buah $(\mathrm{cm})$ & 8,57 & 13,34 \\
Rata-rata diameter buah $(\mathrm{cm})$ & 8,43 & 10,07 \\
Warna Kulit buah & Agak kuning & Agak kuning \\
Rata-rata buah kupas yang dihasilkan (\%) & 72,77 & 76,34 \\
Rata-rata rendemen sari buah yang dihasilkan (\%) & 61,05 & 64,55 \\
\hline
\end{tabular}

Keterangan: Prosentase buah kupas dan sari buah dihitung dari bobot buah utuh

Mengacu kepada Direktorat Budidaya Tanaman Buah (2010), nanas Queen terbagi menjadi 4 grade standar mutu, yaitu: super, A, B, dan C, yangmana faktor pembeda diantara grade tersebut hanya ukuran dan bobot buah, yaitu grade B panjangnya $10-13,9 \mathrm{~cm}$ dan bobotnya $0,4-0,69 \mathrm{~kg}$, sedangkan grade $\mathrm{C}$ panjangnya $\leq 9,9 \mathrm{~cm}$ dan bobotnya $\leq 0,4 \mathrm{~kg}$.

Tabel 1 diatas menampilkan nilai rata-rata buah pada kondisi tanpa mahkota, yaitu: grade $\mathrm{C}$ bobotnya $324,83 \mathrm{~g}$ dan tingginya $8,57 \mathrm{~cm}$; sedangkan untuk grade $\mathrm{B}$ bobotnya $698 \mathrm{~g}$ dan tingginya $13,34 \mathrm{~cm}$. Hal tersebut menunjukkan bahwa buah yang digunakan telah sesuai dengan standar mutu nanas dari Direktorat Budidaya Tanaman Buah (2010). 
Rata-rata bobot nanas Queen grade B sebesar $698 \mathrm{~g}$ yang berarti ukurannya tergolong besar dan telah mendekati standar mutu grade $A$.

Buah nanas Queen grade C dan grade B yang dipakai pada penelitian ini samasama telah berwarna agak kuning yang menunjukkan bahwa buah nanas yang digunakan telah matang. Sebagaimana menurut Paull \& Duarte (2011) dan Siddiq (2012), bahwa kulit nanas yang menguning merupakan tanda buah telah matang. Cahyono (2012) menegaskan buah nanas matang petik bilamana sebanyak 30-50\% kulit buah menguning, dan matang pohon bilamana $60-80 \%$ kulit buah menguning.

Prosentase buah kupas dan rendemen sari buah nanas Queen grade C lebih kecil dari yang dihasilkan oleh grade $\mathrm{B}$. Hal ini dikarenakan nanas grade $\mathrm{C}$ memiliki ukuran yang lebih kecil sehingga memiliki lebih banyak prosentase bagian yang terbuang seperti mahkota dan kulit buah.

\section{Hasil Analisa Karakteristik Sari Buah Nanas}

Sari buah nanas pada penelitian ini diperoleh dengan cara diekstrak langsung dari bubur buahnya dan tanpa penambahan bahan lainnya, sehingga memenuhi kriteria sebagai sari buah. Hal ini didasarkan pada Featherstone (2016) dan Sinha et al., (2012) yang menyampaikan bahwa sari buah atau fruit juice merupakan produk yang terdiri dari $100 \%$ buah. Sari buah nanas Queen grade C dan grade B dianalisa sifat kadar air, total gula, total asam, total padatan terlarut, warna, dan viskositas dengan rata-rata hasil sebagaimana Tabel 2.

Tabel 2. Rata- Rata Karakteristik Sari Buah Nanas Queen Grade C dan Grade B

\begin{tabular}{ccc}
\hline Karakteristik & \multicolumn{2}{c}{ Nanas Queen } \\
\cline { 2 - 3 } & Grade C & Grade B \\
\hline TPT ('brix) & 15,90 & 15,97 \\
Kadar air (\%) & 83,27 & 83,73 \\
Total gula (\%) & 14,98 & 13,96 \\
Total asam (\%) & 1,01 & 1,08 \\
Viskositas (cP) & 5,00 & 2,33 \\
Warna notasi L & 23,63 & 23,73 \\
Warna notasi a* $^{*}$ & 6,17 & 6,20 \\
Warna notasi b* $^{*}$ & 9,53 & 9,03 \\
\hline
\end{tabular}

Tabel 2 diatas menunjukkan bahwa rata-rata TPT sari buah nanas Queen grade C $15,90^{\circ}$ brix dan grade B $15,9^{\circ}$ brix. Hasil tersebut menunjukkan bahwa kedua buah nanas telah sama-sama matang, sesuai dengan Sinha et al., (2012) yang menyampaikan bahwa salah satu ciri buah nanas matang adalah TPT minimum $12^{\circ}$ brix. Sesuai pula dengan Paull \& Duarte (2011) dan Siddiq (2012) yang menyampaikan sebagian konsumen menetapkan TPT nanas matang minimal adalah $14^{\circ}$ brix

Mengacu pada Tabel 2 diatas, baik sari buah nanas Queen grade C maupun grade B masih memenuhi kriteria sebagai sari buah nanas segar, dikarenakan masih memiliki karakteristik TPT, total gula dan total asam yang masih sesuai dengan data-data Sinha et al., (2012), yang menyatakan bahwa sari buah nanas yang masih segar memiliki 
beberapa unsur penting, yaitu: nilai TPT 11,2-16,2 g/100g; total asam 0,46-1,21 g/100 ml; fruktosa 1,72-4,75 g/100 ml; glukosa 1,21-4,52 g/100 ml; dan sukrosa 2,45-9,73 g/100 (total fruktosa, glukosa, dan sukrosa adalah 5,38-19,00 g/100 ml).

Pada pengukuran warna, skala notasi $L$ (lightness) axis $0=$ hitam dan $100=$ putih; notasi a (merah-hijau) axis positif $=$ merah, negatif $=$ hijau, dan $0=$ netral; notasi $b$ (birukuning) nilai positif $=$ kuning, negatif $=$ biru, dan $0=$ netral (Jha, 2010). Tabel 2 menunjukkan bahwa baik sari buah nanas Queen grade $C$ maupun grade $B$, sama-sama memiliki nilai $a^{*}$ dan $b^{*}$ yang positif dan notasi $L<25$, yang menunjukkan bahwa warnanya dominan kuning dan agak gelap. Berdasarkan hal ini, maka baik nanas Queen grade C maupun grade B telah sama-sama matang dan memenuhi standar sebagaimana Direktorat Budidaya Tanaman Buah (2010), yang menyampaikan bahwa warna buah nanas Queen seluruh grade adalah sama, yaitu agak kuning.

\section{Hasil Analisa Karakteristik Konsentrat Sari Buah Nanas}

Konsentrat sari buah nanas pada penelitian ini diperoleh dengan cara evaporasi vakum sari buah dan tanpa penambahan bahan lain, sehingga memenuhi kriteria sebagai konsentrat sari buah. Hal ini sesuai dengan Codex Alimentarius (2005) dan BPOM (2016) yang mendefinisikan konsentrat sari buah adalah sari buah yang dipekatkan dengan cara menghilangkan sebagian airnya untuk meningkatkan jumlah total padatan atau nilai brix. Konsentrat sari buah nanas Queen grade C dan grade B dianalisa sifat kadar air, total gula, total asam, total padatan terlarut, warna, dan viskositas dengan rata-rata hasil sebagaimana Tabel 3.

Tabel 3. Rata-Rata Karakteristik Konsentrat Sari Buah Nanas Queen Grade C dan Grade B

\begin{tabular}{ccc}
\hline Karakteristik & \multicolumn{2}{c}{ Nanas Queen } \\
\cline { 2 - 3 } & Grade C & Grade B \\
\hline TPT ('brix) & 63,40 & 63,57 \\
Kadar air (\%) & 31,80 & 33,53 \\
Total gula (\%) & 57,95 & 61,39 \\
Total asam (\%) & 2,63 & 2,50 \\
Viskositas (cP) & 293,00 & 211,33 \\
Warna notasi L & 25,93 & 25,27 \\
Warna notasi a* & 8,00 & 7,57 \\
Warna notasi b* $^{*}$ & 13,33 & 12,57 \\
\hline
\end{tabular}

Mengacu Tabel 3, nilai TPT konsentrat sari buah nanas Queen grade C sebesar $63,40^{\circ}$ brix dan yang grade $\mathrm{B}$ sebesar $63,5^{\circ} \mathrm{brix}$. Hal ini menunjukkan bahwa kedua grade sari buah nanas tersebut sama-sama dipekatkan dan hasilnya dapat memenuhi syarat minimal TPT pada Codex Alimentarius (2005) yang menetapkan minimum TPT konsentrat sari buah nanas adalah $62,8^{\circ}$ brix. Sesuai pula dengan BPOM (2016) yang menetapkan TPT minimum konsentrat sari buah nanas adalah $40 \%$.

Tabel 3 juga menunjukkan bahwa dibandingkan antara sari buah dengan konsentratnya, terdapat peningkatan nilai TPT, total gula, total asam, viskositas dan warna. Kondisi ini dikarenakan terdapat sejumlah air yang dibuang dengan cara diuapkan pada 
proses pemekatan sehingga terdapat peningkatan prosentase total gula dan total asam, yang ditunjukkan dengan peningkatan TPT, viskositas dan warna yang semakin tajam. Hal ini berdasarkan tinjauan bahwa TPT pada sari buah menunjukkan jumlah total konstituen terlarut, yangmana sebagian besar adalah gula dan sebagian kecil asam organik, vitamin, protein, asam amino bebas, minyak esensial dan glukosida (Hardy \& Sanderson, 2010).

\section{Hasil Analisa Komparatif Sifat Sari Buah Nanas}

Pada tahap ini terdapat penghitungan nilai rerata, varian dan $t_{\text {hitung }}$ terhadap hasil analisa sifat sari buah nanas Queen grade $\mathrm{C}$ dan grade $\mathrm{B}$. Hasil analisa $t$-test independent terhadap karakteristik tersebut sebagaimana pada Tabel 4.

Tabel 4. Hasil Analisa t-test independent Terhadap Karakteristik Sari Buah Nanas Queen Grade C dengan Grade B

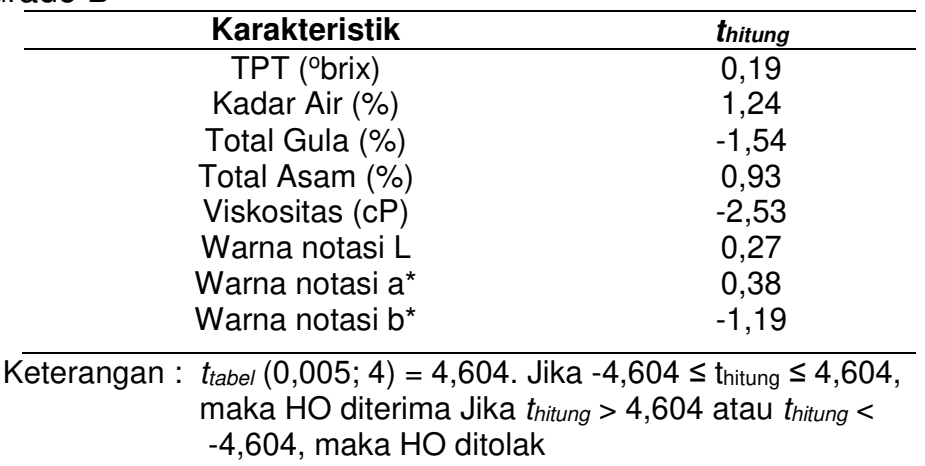

Analisa komparatif t-test independent menunjukkan bahwa seluruh nilai thitung pada rentang nilai (-)4,604 sampai dengan (+)4,604 sehingga seluruh HO diterima, yang berarti tidak ada perbedaan rata-rata sifat fisikokimia antara sari buah nanas Queen grade C dengan grade B. Hasil ini menunjukkan bahwa tidak terdapat perbedaan tingkat kematangan antara nanas Queen grade $C$ dengan grade B. Hasil ini sesuai dengan Direktorat Budidaya Tanaman Buah (2010), yang menyatakan bahwa nanas Queen grade super, $\mathrm{A}, \mathrm{B}$, dan $\mathrm{C}$ memiliki kadar gula yang sama yaitu minimal $11^{\circ} \mathrm{Brix}$, dan warna yang sama yaitu agak kuning. Sesuai pula dengan pernyataan Penyuluh Pertanian Kabupaten Kediri yang bertugas di Gunung Kelud, bahwa nanas Queen grade $\mathrm{C}$ merupakan buah yang matang, sama dengan tingkat kematangan grade yang lain, namun berukuran lebih kecil.

\section{Hasil Analisa Komparatif Sifat Konsentrat Sari Buah Nanas}

Tabel 5. Hasil Analisa t-test independent Terhadap Karakteristik Konsentrat Sari Buah Nanas Queen Grade C dengan Grade B

\begin{tabular}{cc}
\hline Karakteristik & $\boldsymbol{t}_{\text {hitung }}$ \\
\hline TPT (obrix) & 0,79 \\
Kadar Air (\%) & 1,20 \\
Total Gula (\%) & 2,56 \\
Total Asam (\%) & $-1,78$ \\
Viskositas (cP) & $-1,21$ \\
Warna notasi L & $-0,92$ \\
Warna notasi a* & $-1,75$ \\
Warna notasi b* & $-0,67$ \\
\hline Keterangan: & ttabel (0,005; 4) =4,604. Jika -4,604 $\leq$ thitung $\leq 4,604$, maka HO \\
diterima Jika thitung $>4,604$ atau thitung $<-4,604$, maka HO & \\
ditolak. &
\end{tabular}


Pada tahap ini terdapat penghitungan nilai rerata, varian dan $t_{\text {hitung }}$ terhadap hasil analisa sifat konsentrat sari buah nanas Queen grade $\mathrm{C}$ dan grade $\mathrm{B}$. Tabel 5 menampilkan hasil analisa $t$-test independent terhadap karakteristik tersebut.

Analisa komparatif $t$-test independent pada Tabel 5 menunjukkan bahwa seluruh nilai thitung pada rentang nilai (-)4,604 sampai dengan (+)4,604 sehingga seluruh $\mathrm{HO}$ diterima, yang berarti tidak ada perbedaan rata-rata sifat fisikokimia antara konsentrat sari buah nanas Queen grade C dengan grade B.

Mengacu pada Tabel 4 dan Tabel 5, menunjukkan bahwa dengan tidak adanya perbedaan rata-rata sifat fisikokimia antara sari buah kedua grade tersebut maka dapat menghasilkan konsentrat yang tidak berbeda pula. Dengan demikian, buah nanas Queen grade $\mathrm{C}$ dapat diolah menjadi sari buah dan konsentrat sari buah, yangmana kualitasnya tidak berbeda dengan yang diolah dari nanas Queen grade B.

Konsentrat sari buah nanas merupakan produk komersiil yang telah banyak diproduksi oleh industri pangan. Elkins et al. (1997) telah melakukan penelitian mengenai karakteristik konsentrat sari buah nanas komersil. Sifat TPT, total asam dan total gula konsentrat sari buah nanas Queen grade $\mathrm{C}$ dibandingkan dengan produk komersiil hasil penelitian Elkins et al. (1997). Sifat-sifat tersebut diperbandingkan dengan pertimbangan bahwa nilai TPT merupakan syarat penting pada konsentrat sari buah, tingkat keasaman merupakan salah satu karakteristik produk yang sering disampaikan oleh pihak produsen, dan kadar total gula berkorelasi dengan kadar gula suatu produk. Tabel 6 menunjukkan perbandingan sifat-sifat tersebut.

Tabel 6. Sifat Konsentrat Sari Buah Nanas Queen Grade C dengan Produk Komersiil

\begin{tabular}{ccccc}
\hline \multirow{2}{*}{ Sifat } & Nanas Queen Grade & \multicolumn{3}{c}{ Produk Komersil } \\
\cline { 3 - 5 } & C & Minimal & Maksimal & Rata-rata \\
\hline TPT ( ${ }^{\circ}$ brix) & 63,40 & 55,20 & 72,70 & 62,00 \\
Total Asam (\%) & 2,63 & 1,90 & 5,00 & 3,10 \\
Total Gula (\%) & 57,95 & 36,90 & 71,90 & 54,00 \\
\hline
\end{tabular}

Keterangan: Karakteristik konsentrat sari buah nanas produk komersil bersumber dari penelitian Elkins et al. (1997)

Berdasarkan tabel 6, nilai TPT, nilai total asam dan total gula masih dalam rentang nilai minimal-maksimal dan mendekati nilai rata-rata produk komersiil pada penelitian Elkins et al. (1997). Hal ini menunjukkan bahwa nanas Queen grade C bisa diolah menjadi konsentrat sari buah yang memiliki nilai TPT, total asam dan total gula yang sesuai dengan produk komersiil yang dihasilkan dari nanas jenis lainnya.

\section{Kesimpulan}

Berdasarkan analisa sifat fisikokimia, dapat disimpulkan sifat fisikokimia sari buah nanas Queen grade C dan grade B memiliki rata-rata nilai TPT, kadar air, total gula, total asam, viskositas, warna La*b*, secara berurutan sebagai berikut: $15,90^{\circ}$ brix dan $15,97^{\circ}$ brix; $83,27 \%$ dan $83,73 \% ; 14,98 \%$ dan $13,96 \% ; 1,01 \%$ dan $1,08 \% ; 5,00 \mathrm{cP}$ dan $2,33 \mathrm{cP} ; 23,63$ 
dan 23,73; 6,17 dan 6,20; 9,53 dan 9,03. Berdasarkan analisa fisikokimia konsentrat sari buah nanas Queen grade C dan grade B juga memiliki rata-rata nilai TPT, kadar air, total gula, total asam, viskositas, warna La*b*, secara berurutan sebagai berikut: $63,40^{\circ}$ brix dan $63,57^{\circ}$ brix; $31,80 \%$ dan $33,53 \%$; $57,95 \%$ dan $61,39 \%$; 2,63\% dan 2,50\%; 293,00 cP dan 211,33 cP; 25,93 dan 25,27; 8,00 dan 7,57; 13,33 dan $12,57$.

Berdasarkan analisa komparatif t-test independent, dapat disimpulkan bahwa tidak terdapat perbedaan rata-rata sifat fisikokimia antara sari buah nanas Queen grade C dengan produk sejenis yang dihasilkan dari nanas Queen grade B, demikian pula tidak terdapat perbedaan rata-rata sifat fisikokimia antara konsentrat sari buah nanas Queen grade C dengan produk sejenis yang dihasilkan dari nanas Queen grade B.

\section{Daftar Pustaka}

Amador, J.R. (2011). Laboratory Manual Procedures For Analysis of Citrus Products. Sixth Edition. John Bean Technologies Corporation Inc. Florida. Lakeland.

Apriyantono, A., D. Fardiaz, N. L. Puspitasari, Sedarnawati, \& S. Budiyanto. (1989). Petunjuk Laboratorium Analisis Pangan. PAU Pangan dan Gizi. Institut Pertanian Bogor. IPB Press. Bogor.

Ashurst, P.R. (2005). Chemistry and Technology of Soft Drinks and Fruit Juices. Second edition. Blackwell Publishing Ltd. Oxford.

Assawarachan, R., \& A. Noomhorm. (2010). Changes in Color and Rheological Behavior of Pineapple Concentrate Through Various Evaporation Methods. International Journal of Agricultural and Biological Engineering. 3(1). 74-83

Badan Pengawas Obat dan Makanan (BPOM). (2016). Peraturan Kepala Badan Pengawas Obat dan Makanan Republik Indonesia Nomor 21 Tahun 2016 Tentang Kategori Pangan. Jakarta.

Badan Pusat Statistik (BPS). (2015). Tabel Produksi Tanaman Buah-Buahan Nenas. Diakses pada 8 November 2016, dari www.bps.go.id.

Cahyono, B. (2012). Buku Terlengkap Budidaya Nenas Secara Komersial. Cetakan pertama. Pustaka Mina. Jakarta.

Codex Alimentarius. 2005. Codex General Standard For Fruit Juices and Nectars (Codex Stan 247-2005). World Health Organization-Food and Agriculture Organization of The United Nations.

Direktorat Budidaya Tanaman Buah. (2010). Standar Prosedur Operasional (SPO) Nenas Jawa Timur. Jakarta.

Elkins, E.R., R. Lyon, C.J. Huang, \& A. Matthys. (1997). Characterization of Commercially Produced Pineapple Juice Concentrate. Journal of Food Composition and Analysis. 10. 285-298.

Falguera, V. \& A. Ibarz. (2014). Juice Processing Quality Safety and Value-Added Opportunities. CRC Press. Taylor \& Francis Group. Boca Raton FL

Featherstone, S. (2016). A Complete Course in Canning and Related Processes. Fourteenth edition. Volume 3. Woodhead Publishing. Elsevier. Cambridge.

Food and Agriculture Organization of The United Nations (FAO UN). (2013). Data Production Crops Pineapple. Retrieved 10 Mei 2016, from Faostat3.fao.org. 
Hardy, S., \& G. Sanderson. (2010). Citrus Maturity Testing. Primefacts for profitable adaptive and sustainaible primary industries. 980. New South Wales. Departement of Industry \& Investment. Retrieved 09 November 2018 from https://www.dpi.nsw.gov.au

Jha, S.H. (2010). Nondestructive Evaluation of Food Quality Theory and Practice. Heidelberg. Springer

Laylatul, L. F. (2014.) Pemanfaatan Nanas (Ananas Comosus L) Subgrade Sebagai Fruit Leather Nanas Guna Mendukung Pengembangan Agroindustri di Kediri Kajian Penambahan Karaginan dan Sorbitol. Fakultas Teknologi Pertanian. Universitas Brawijaya. Malang. Skripsi

Paull, R.E., \& O. Duarte. (2011). Tropical Fruits. Second edition. Volume 1. CAB International. Wallingford Oxfordshire.

Samadi, B. 2014. Panen Untung dari Budi Daya Nanas Sistem Organik. Lily Publisher. Yogyakarta

Septivirta, T.D.T. (2014). Pembuatan Permen Jelly dari Buah Nanas (Ananas comosus L) Subgrade (Kajian Konsentrasi Karagenan dan Gelatin). Fakultas Teknologi Pertanian. Universitas Brawijaya. Malang. Skripsi.

Siddiq, M. (2012). Tropical and Subtropical Fruits Postharvest Physiology Processing and Packaging. First edition. Wiley-Blackwell. John Wiley \& Sons Inc. Ames lowa.

Sinha, N., J. Sidhu, J. Barta, J. Wu, \& M.P. Cano. (2012). Handbook of Fruits and Fruit Processing. Second edition. Wiley-Blackwell. John Wiley \& Sons Ltd. Ames lowa.

Siregar, S. (2015). Statistik Parametrik Untuk Penelitian Kuantitatif. Edisi Pertama. Cetakan Ketiga. PT Bumi Aksara. Jakarta.

Sudarmadji, S., B. Haryono, \& Suhardi. (2010). Prosedur Analisa Untuk Bahan Makanan dan Pertanian. Edisi Keempat. Cetakan Ketiga. Liberty Yogyakarta. Yogyakarta.

Wijayanti, F.N. (2014). Pembuatan Permen Coklat Praline dengan Filler Permen Jelly Nanas (Kajian Konsentrasi Penambahan Karaginan dan Sukrosa). Fakultas Teknologi Pertanian. Universitas Brawijaya. Malang. Skripsi. 